\title{
Analisis Faktor Dalam Meningkatkan Prestasi Belajar Siswa Kelas X IPS SMA Negeri 1 Adonara Timur, Provinsi
}

\author{
Maria Prisca ${ }^{(1)}$, Artanti Indrasetianingsih ${ }^{(2)}$ \\ ${ }^{1,2)}$ Universitas PGRI Adi Buana Surabaya \\ Jl. Dukuh Menanggal XII Telp./Fax. (031) 822289873 Surabaya 60234 \\ e-mail: maria08prisca@gmail.com dan artanti.indra@unipasby.ac.id
}

\begin{abstract}
ABSTRAK
Pendidikan merupakan hal yang sangat penting dalam mencapai cita-cita bangsa sehingga meningkatkan Sumber Daya Manusia yang berkualitas. Perubahan Kurikulum pada tahun 2013 merupakan upaya pemerintah dalam meningkatkatkan kualitas pendidikan di Indonesia yang diketahui berdasarkan prestasi belajar siswa. Untuk meningkatkan prestasi belajar siswa, diperlukan faktor intern dan faktor ekstern yang mendorong siswa untuk tetap semangat dalam belajar. Prestasi belajar di SMA Negeri 1 Adonara Timur khususnya kelas X tergolong baik, Namun, prestasi belajar pada kelas X IPS seringkali rendah. Penelitian ini bertujuan untuk mengetahui faktor-faktor apa saja yang terbentuk dalam meningkatkan prestasi belajar siswa kelas X IPS di SMA Negeri 1 Adonara Timur. Data yang digunakan dalam penelitian ini adalah data primer yang diperoleh melalui penyebaran kuesioner, dengan sampel sebanyak 47 siswa. Metode analisis yag digunakan dalam penelitian ini adalah analisis faktor. Tujuan dari analisis faktor pada penelitian ini adalah untuk mereduksi data maka metode analisis faktor yang digunakan adalah Principal Component Analysis (PCA). Hasil dari penelitian ini diperoleh 5 faktor yang diduga dapat meningkatkan prestasi belajar siswa kelas X IPS di SMA Negeri 1 Adonara Timur. Faktor-faktor tersebut adalah Lingkungan Sekolah, Peranan Orang Tua, Peranan Guru, Disilpin Belajar, dan Motivasi Belajar.
\end{abstract}

Kata kunci : Angka Harapan Hidup, Regresi Linier Berganda, Moran's I, Spatial Autoregressive Model.

\begin{abstract}
Education is very important in achieving the ideals of the nation to improve the quality of human resources as well. Curriculum change in 2013 is one of the government's efforts in improving the quality of education in Indonesia. To improve students' learning achievement, internal and external factors are needed to encourage students to keep their spirit in learning. In this study, the researcher took a case about factor analysis in improving the achievement of the students of class X IPS of SMA Negeri 1 Adonara Timur. Achievement of study in SMA Negeri 1 Adonara East class X particularly good, although there are achievement of learning in class X IPS is often low. This study aims to determine what factors are formed in improving student achievement class X IPS in SMA Negeri 1 Adonara Timur. The data used in this study is the primary data obtained through the distribution of questionnaires, with a sample of 47 students. The analysis method used in this research is factor analysis. Factor analysis is one of the statistical techniques that can be used to provide a relatively simple description through the reduction of the number of variables called factors. Since the purpose of factor.
\end{abstract}

Keywords : Life Expectancy, Multiple Linier Regression, Moran's I, Spatial Autoregressive Model.

\section{PENDAHULUAN}

Pendidikan adalah salah satu kebutuhan utama dalam mencapai cita-cita bangsa, yang secara sadar dilakukan oleh setiap orang sepanjang masa. Pendidikan merupakan dasar yang penting bagi kemajuan sebuah bangsa, karena dengan adanya pendidikan sebuah bangsa mampu mencapai kemajuan, baik dalam pembangunan sumber daya manusia maupun pada pengolahan sumber daya alam. Salah satu cara peningkatan sumber daya manusia adalah melalui peningkatan mutu pendidikan, karena dengan mutu pendidikan yang berkualitas akan menghasilkan sumber daya manusia yang berkualitas pula.

Cara untuk meningkatkan kualitas pendidikan adalah dengan melihat prestasi belajar. Prestasi belajar merupakan kesempurnaan yang dicapai se- 
seorang dalam berfikir, merasa dan berbuat (Nasution, 2009). Prestasi belajar adalah penilaian terhadap hasil belajar yang dinyatakan dengan angka maupun huruf yang mencerminkan hasil yang diperoleh peserta didik dalam suatu pembelajaran pada periode tertentu. Hingga saat ini pun prestasi belajar masih tetap digunakan sebagai tolak ukur untuk menilai tingkat keberhasilan siswa dalam proses belajar. Ada siswa yang memperoleh prestasi belajar yang tinggi tetapi tidak jarang ada siswa yang memperoleh pretasi belajar yang rendah.

Prestasi belajar siswa merupakan suatu hal yang sangat diinginkan oleh setiap guru maupun orang tua. Selain guru dan orangtua, setiap siswa juga pasti menginginkan dirinya dapat berprestasi baik atau dengan kata lain hasil belajarnya dapat tercapai secara maksimal. Akan tetapi, untuk mencapai keinginan tersebut tidaklah mudah. Siswa dituntut untuk belajar supaya bisa mendapatkan prestasi yang baik.

Untuk meningkatkan prestasi belajar siswa, banyak cara yang dilakukan salah satunya adalah dengan mengikuti bimbingan belajar di luar waktu sekolah. Namun hal itu tidak terlepas dari faktor intern dan faktor ekstern. Faktor intern yaitu faktor yang ada dalam diri individu itu. Adapun yang termasuk dalam faktor intern antara lain, motivasi, sikap, minat, bakat, dan konsentrasi. Sedangkan faktor ekstern yaitu faktor yang ada di luar individu itu sendiri. Faktor tersebut antara lain faktor keluarga, faktor sekolah, dan faktor masyarakat.

Berdasarkan penelitian terdahulu yang dilakukan oleh Farida Nursari (2013) tentang "Faktor-Faktor yang Mempengaruhi Prestasi Belajar Siswa Kelas XI IPS SMA Negeri Ponorogo". Hasil dari penelitian tersebut menunjukkan bahwa terdapat sembilan faktor yang terbentuk mempengaruhi prestasi belajar siswa kelas XI IPS SMA Negeri Ponorogo. Faktor-faktor tersebut adalah faktor keluarga, faktor sekolah dan mass media, faktor sikap dan pendekatan belajar, faktor fisiologis dan waktu pelaksanaan pembelajaran, faktor pendukung pembelajaran, faktor kesehatan, faktor tugas rumah, faktor pergaulan dan faktor pancaindra dan standar pelajaran.

SMA Negeri 1 Adonara Timur merupakan satusatunya SMA Negeri yang berada di Adonara, Provinsi Nusa Tenggara Timur, Kabupaten Flores Timur, Kecamatan Adonara Timur. Berdasarkan penerapan kurikulum 2013 yang bakal berdampak signifikan pada jenjang SMA, diperoleh gambaran bahwa penjurusan jenjang SMA lebih baik dimulai sejak kelas X. Dengan demikian siswa bisa lebih mendalami bidang keilmuan yang diminatinya sejak dini. Oleh karena itu, SMA Negeri 1 Adonara Timur mengharuskan siswa untuk melakukan penjurusan dari Kelas X diantaranya adalah jurusan IPA, IPS dan Bahasa.

Informasi yang diperoleh dari hasil wawancara yang dilakukan dengan seorang guru kelas X di SMA Negeri 1 Adonara Timur yang mengatakan dalam kegiatan pembelajaran di kelas $\mathrm{X}$ masih terdapat hal yang kurang maksimal. Contoh kasusnya adalah siswa kurang aktif dan siswa kurang semangat dalam proses belajar sehingga menyebabkan prestasi belajar kurang baik. Namun, tidak semua siswa kelas X memiliki prestasi belajar yang kurang baik. Prestasi belajar siswa kelas X di SMA Negeri Adonara Timur memang fluktuatif. Artinya, ada siswa yang mendapat nilai tinggi dan ada juga siswa yang mendapat nilai rendah. Akan tetapi, sejauh ini prestasi belajar siswa kelas X di SMA Negeri Adonara Timur bisa dikatakan baik. Prestasi Belajar setiap kelas X di SMA Negeri 1 Adonara Timur berbeda-beda. Prestasi Belajar siswa kelas X IPA berbeda dengan kelas X IPS dan kelas X Bahasa, begitu juga sebaliknya. Di SMA Negeri 1 Adonara Timur prestasi belajar siswa yang seringkali rendah terdapat pada kelas X IPS.

Berdasarkan uraian di atas, maka perlu dilakukan penelitian terkait faktor-faktor dalam meningkatkan prestasi belajar siswa kelas X di SMA Negeri 1 Adonara Timur dengan menggunakan analisis faktor. Penelitian dilakukan pada kelas $\mathrm{X}$ IPS. Analisis ini dilakukan untuk mereduksi variabel-variabel yang dapat meningkatkan prestasi belajar siswa kelas X IPS di SMA Negeri 1 Adonara Timur. Hasil dari reduksi menunjukan faktor-faktor apa saja yang terbentuk dalam meningkatkan prestasi belajar siswa kelas X IPS di SMA Negeri 1 Adonara Timur.

Tujuan dari penelitian ini adalah untuk mengetahui faktor-faktor apa saja yang terbentuk dalam meningkatkan prestasi belajar siswa kelas $\mathrm{X}$ IPS di SMA Negeri 1 Adonara Timur menggunakan analisis faktor.

\section{METODE PENELITIAN}

Data yang digunakan dalam penelitian ini adalah data primer. Data primer diperoleh dengan menggunakan daftar pernyataan yang telah disusun dalam kuesioner. Kuesioner dalam penelitian ini berupa pernyataan-pernyataan yang dapat meningkatkan prestasi belajar siswa. Kuesioner tersebut disebarkan di SMA Negeri 1 Adonara Timur dengan respondenya adalah siswa kelas X IPS. Dengan populasi kelas X sebanyak 89 siswa yang terdiri dari 3 kelas yaitu X IPS I, X IPS II, dan X IPS III. Sampel yang digunakaN dalam penelitian ini sebanyak 47 siswa, yang kemudian diambil sampel 
pada masing-masing kelas yaitu pada kelas X IPS I sampel yang diambil sebanyak 16 siswa, kelas X IPS II sebanyak 16 siswa, dan kelas X IPS III sebanyak 15 siswa. Variabel-variabel yang digunakan dalam penelitian yaitu:

Tabel 1. Variabel Penelitian

\begin{tabular}{|c|c|}
\hline No. & Variabel \\
\hline $\mathrm{X}_{1}$ & Guru selalu tepat waktu \\
\hline $\mathrm{X}_{2}$ & $\begin{array}{l}\text { Guru membantu siswa jika mengalami } \\
\text { kesulitan }\end{array}$ \\
\hline$X_{3}$ & $\begin{array}{l}\text { Guru mampu menciptakan rasa nyaman } \\
\text { dalam belajar di kelas }\end{array}$ \\
\hline $\mathrm{X}_{4}$ & $\begin{array}{l}\text { Guru mampu menjelaskan materi } \\
\text { pelajaran bagi siswa yang belum } \\
\text { memahaminya }\end{array}$ \\
\hline $\mathrm{X}_{5}$ & $\begin{array}{l}\text { Cara mengajar guru menumbuhkan } \\
\text { semangat }\end{array}$ \\
\hline $\mathrm{X}_{6}$ & $\begin{array}{l}\text { Karakter guru yang baik membuat saya } \\
\text { bersemangat belajar }\end{array}$ \\
\hline $\mathrm{X}_{7}$ & $\begin{array}{l}\text { Orang tua mengatur dan memonitor } \\
\text { waktu belajar }\end{array}$ \\
\hline $\mathrm{X}_{8}$ & $\begin{array}{l}\text { Orang tua memberikan semangat saat } \\
\text { mendapat hasil belajar yang } \\
\text { kurang/tidak memuaskan }\end{array}$ \\
\hline $\mathrm{X}_{9}$ & $\begin{array}{l}\text { Pujian orang tua terhadap hasil belajar } \\
\text { yang memuaskan }\end{array}$ \\
\hline $\mathrm{X}_{10}$ & $\begin{array}{l}\text { Orang tua memperhatikan kepentingan } \\
\text { dan kebutuhan belajar }\end{array}$ \\
\hline $\mathrm{X}_{11}$ & $\begin{array}{l}\text { Ambisi untuk berhasil dalam belajar } \\
\text { sangat tinggi }\end{array}$ \\
\hline $\mathrm{X}_{12}$ & $\begin{array}{l}\text { Memiliki harapan dan cita-cita dimasa } \\
\text { depan }\end{array}$ \\
\hline $\mathrm{X}_{13}$ & Membuat jadwal belajar sendiri \\
\hline $\mathrm{X}_{14}$ & $\begin{array}{l}\text { Tetap giat belajar, apabila nilai ulangan } \\
\text { yang diperoleh baik }\end{array}$ \\
\hline$X_{15}$ & $\begin{array}{l}\text { Mencari solusi saat mengalami } \\
\text { kesulitan belajar }\end{array}$ \\
\hline $\mathrm{X}_{16}$ & $\begin{array}{l}\text { Mempelajari/mengulang kembali materi } \\
\text { di rumah }\end{array}$ \\
\hline $\mathrm{X}_{17}$ & $\begin{array}{l}\text { Mengerjakan sendiri tugas yang } \\
\text { diberikan guru }\end{array}$ \\
\hline $\mathrm{X}_{18}$ & Memperhatikan penjelasan guru \\
\hline $\mathrm{X}_{19}$ & $\begin{array}{l}\text { Bertanya kepada guru jika belum } \\
\text { memahami penjelasanya }\end{array}$ \\
\hline$X_{20}$ & Mencatat penjelasan penting dari guru \\
\hline $\mathrm{X}_{21}$ & $\begin{array}{l}\text { Mempelajari bahan pelajaran sebelum } \\
\text { proses belajar dimulai }\end{array}$ \\
\hline $\mathrm{X}_{22}$ & Mengerjakan tugas tetap waktu \\
\hline $\mathrm{X}_{23}$ & $\begin{array}{l}\text { Izin ke guru jika ingin meninggalkan } \\
\text { kelas }\end{array}$ \\
\hline $\mathrm{X}_{24}$ & $\begin{array}{l}\text { Manfaatkan waktu untuk belajar ketika } \\
\text { guru berhalangan }\end{array}$ \\
\hline
\end{tabular}

Tabel 1. (Lanjutan) Variabel Penelitian

\begin{tabular}{|l|l|}
\hline No. & \multicolumn{1}{|c|}{ Variabel } \\
\hline $\mathrm{X}_{25}$ & $\begin{array}{l}\text { Rasa ingin tau terhadap pelajaran } \\
\text { sangat tinggi }\end{array}$ \\
\hline $\mathrm{X}_{26}$ & Melaksanakan tugas piket \\
\hline $\mathrm{X}_{27}$ & $\begin{array}{l}\text { Memiliki hubungan yang harmonis } \\
\text { dengan guru }\end{array}$ \\
\hline $\mathrm{X}_{28}$ & $\begin{array}{l}\text { Memiliki hubungan yang harmonis } \\
\text { dengan teman }\end{array}$ \\
\hline $\mathrm{X}_{29}$ & $\begin{array}{l}\text { Lingkungan sekolah yang bersi dan } \\
\text { nyaman }\end{array}$ \\
\hline $\mathrm{X}_{30}$ & Kelengkapan fasilitas di sekolah \\
\hline
\end{tabular}

Metode analisis yang digunakan dalam penelitian ini adalah analisis faktor. Adapun langkah-langkah penelitian adalah sebagai berikut:

1. Menyusun Kuesioner

Tahap awal dari pelaksanaan analisis faktor adalah dengan menyusun kuesioner terlebih dahulu.

2. Pengambilan data

Setelah menyusun kuesioner, maka tahap selanjutnya akan dilakukan pengambilan data.

3. Melakukan analisis deskriptif dari karateristik responden (siswa kelas X IPS SMA Negeri 1 Adonara Timur).

4. Melakukan uji validitas dengan menggunakan korelasi Product Moment Person dan uji reliabilitas dengan menggunakan teknik pengukuran Alpha Cronbach.

5. Melakukan uji syarat kecukupan data

Di dalam melakukan analisis faktor, keputusan pertama yang harus diambil adalah menganalisis apakah data yang ada cukup memenuhi syarat di dalam analisis faktor. Langkah pertama ini dilakukan dengan mencari korelasi matriks. Ada beberapa ukuran yang bisa digunakan untuk syarat kecukupan data yaitu:

- Uji Bartlett

- Uji Kaiser-Meyer Olkin (KMO)

- Uji Measure of Sampling Adequacy (MSA)

6. Ektraksi faktor dilakukan dengan metode Principal Component Analysis.

7. Menentuan jumlah faktor dengan melihat nilai eigenvalue yang lebih besar dari 1 (satu).

8. Merotasi faktor dengan menggunakan rotasi orthogonal dengan varimax.

9. Interpretasikan faktor

10. Kesimpulan

\section{HASIL DAN PEMBAHASAN 3.1 Uji Validitas}

Uji validitas dilakukan dengan tujuan untuk mengetahui sejauh mana ketepatan dan kecermatan suatu instrumen pengukuran dalam melakukan 
fungsi ukurnya. Dalam penelitian ini pengujian validitas dilakukan terhadap 47 responden. Pengambilan keputusan berdasarkan pada nilai r-hitung (Corrected Item- Total Correlation) > r-tabel sebesar 0,287 untuk df $=47-2=45 ; \alpha=0,05$ maka item pernyataan tersebut valid atau sebaliknya.

Pada penelitian ini uji validitas dilakukan sebanyak 4 tahap untuk mengetahui apakah semua variabel valid atau tidak. Berikut hasil uji validitas tahap 1 (satu):

Tabel 2. Uji Validitas Tahap 1

\begin{tabular}{crc}
\hline Variabel & r (item, total) & Keputusan \\
\hline X1 & $\mathbf{0 , 1 4 4 6}$ & Tidak Valid \\
X2 & 0,3195 & Valid \\
X3 & 0,3756 & Valid \\
X4 & $\mathbf{0 , 1 3 8 2}$ & Tidak Valid \\
X5 & 0,6528 & Valid \\
X6 & 0,3310 & Valid \\
X7 & 0,2934 & Valid \\
X8 & 0,4752 & Valid \\
X9 & 0,3397 & Valid \\
X10 & 0,3410 & Valid \\
X11 & 0,4774 & Valid \\
X12 & $\mathbf{0 , 2 5 9 7}$ & Tidak Valid \\
X13 & 0,3386 & Valid \\
X14 & 0,3656 & Valid \\
X15 & 0,3896 & Valid \\
X16 & 0,6150 & Valid \\
X17 & 0,3938 & Valid \\
X18 & 0,3660 & Valid \\
X19 & 0,4417 & Valid \\
X20 & 0,3909 & Valid \\
X21 & $\mathbf{0 , 1 6 2 6}$ & Tidak Valid \\
X22 & 0,4096 & Valid \\
X23 & $\mathbf{0 , 2 7 4 6}$ & Tidak Valid \\
X24 & 0,4783 & Valid \\
X25 & 0,3536 & Valid \\
X26 & $\mathbf{0 , 2 5 3 7}$ & Tidak Valid \\
X27 & 0,4464 & Valid \\
X28 & 0,3806 & Valid \\
X29 & 0,3989 & Valid \\
X30 & $\mathbf{0 , 1 2 7 1}$ & Tidak Valid \\
\hline & & \\
\hline
\end{tabular}

Berdasarkan hasil Tabel 2 di atas diketahui bahwa terdapat 7 (tujuh) variabel (item pernyataan) yang tidak valid yaitu pada variabel guru tepat waktu memulai dan mengakhiri pelajaran (X1), guru mampu menjelaskan materi pelajaran bagi siswa yang belum memahaminya (X4), siswa memiliki harapan dan cita-cita dimasa depan (X12), siswa mempelajari bahan ajar sebelum proses belajar dimulai (X21), siswa izin ke guru jika meninggalkan kelas (X23), siswa melaksanakan tugas piket (X26) dan fasilitas di sekolah lengkap (X30). Hal ini disebabkan karena nilai corrected item-total correlation pada masing-masing variabel tersebut kurang dari nilai r-tabel yaitu 0,287, sehingga 7 (tujuh) variabel tersebut harus dikeluarkan dari analisis dan dilakukan pengujian ulang untuk melihat masih adanya variabel yang tidak valid.

Pada hasil pengujian validitas tahap kedua (pada lampiran 2) didapatkan hasil bahwa terdapat dua variabel yang tidak valid yaitu pada variabel orang tua mengatur dan memonitor waktu belajar siswa (X7) dan orang tua memperhatikan kebutuhan belajar siswa (X10), maka variabel tersebut dikeluarkan dari analisis dan kemudian dilakukan pengujian ulang validitas tahap ketiga. Pada hasil pengujian validitas tahap ketiga (pada lampiran 3) diketahui bahwa terdapat dua variabel yang tidak valid lagi yaitu yaitu pada variabel lingkunga sekolah yang bersih dan nyaman (X29), sehingga variabel tersebut dikeluarkan dari analisis dan dilakukan pengujian ulang untuk melihat apakah variabel yang tersisa valid atau tidak.

Berikut adalah hasil uji validitas untuk 20 variabel yang tersisa, pada Software R :

Tabel 3. Uji Validitas Tahap 4

\begin{tabular}{crr}
\hline Variabel & r (item,total) & Keputusan \\
\hline X2 & 0,323 & Valid \\
X3 & 0,337 & Valid \\
X5 & 0,686 & Valid \\
X6 & 0,364 & Valid \\
X8 & 0,512 & Valid \\
X9 & 0,337 & Valid \\
X11 & 0,523 & Valid \\
X13 & 0,352 & Valid \\
X14 & 0,329 & Valid \\
X15 & 0,373 & Valid \\
X16 & 0,609 & Valid \\
X17 & 0,406 & Valid \\
X18 & 0,354 & Valid \\
X19 & 0,446 & Valid \\
X20 & 0,355 & Valid \\
X22 & 0,441 & Valid \\
X24 & 0,543 & Valid \\
X25 & 0,298 & Valid \\
X27 & 0,473 & Valid \\
X28 & 0,303 & Valid \\
\hline
\end{tabular}

Setelah dilakukan pengujian ulang validitas tahap keempat yang dapat dilihat pada Tabel 3 di atas, Hasil menunjukan bahwa nilai korelasi masingmasing variabel > r tabel $(0,167)$. Oleh karena itu dapat disimpulkan bahwa dari ke 33 variabel sudah valid dan dapat dilakukan uji reliabilitas.

\subsection{Uji Reliabilitas}

Uji reliabilitas dilakukan untuk mengukur suatu instrumen cukup dapat dipercaya digunakan sebagai alat pengumpulan data karena instrumen tersebut sudah cukup baik. Reliabilitas merupakan 
syarat untuk tercapainya validitas suatu kuesioner dengan tujuan tertentu. Teknik pengumpulan data yang digunakan adalah Cronbach's Alpha.

Berdasarkan hasil uji pada software R diketahui bahwa nilai Cronbach's Alpha sebesar 0,831 lebih besar dari 0,6. Hal ini dapat disimpulkan bahwa semua item pernyataan reliabel yang berarti instrumen yang digunakan cukup dapat dipercaya sebagai alat pengumpulan data.

\subsection{Analisis Faktor}

Analisis Faktor merupakan suatu analisis yang bertujuan untuk mereduksi sejumlah variabel asal yang jumlahnya banyak menjadi sejumlah variabel baru yang jumlahnya lebih sedikit dari variabel asal. Variabel baru tersebut dinamakan faktor atau variabel laten atau konstruk atau variabel bentukan.

\section{Barlett's Test}

Pengujian ini dilakukan untuk membantu mengidentifikasi korelasi antar variabel. Berdasarkan landasan teori bahwa hipotesis untuk uji korelasi ini adalah sebagai berikut:

$\mathrm{H}_{0}$ : Matriks korelasi adalah matriks identitas

$\mathrm{H}_{1}$ : Matriks korelasi bukan matriks identitas

Berikut adalah hasil uji Barlett's menggunakan software $R$ :

Tabel 4. Bartlett's Test

\begin{tabular}{lr}
\hline \multicolumn{2}{r}{ Bartlett's Test of Sphericity } \\
\hline Khi-Squared & 298,92 \\
Df & 158 \\
Sig. & $1,709 \mathrm{e}-11$ \\
\hline
\end{tabular}

Dalam analisis faktor hasil Barlett's Test yang diinginkan adalah adanya korelasi diantara suatu variabel. Berdasarkan hasil output pada Tabel 4 dapat diketahui bahwa antar variabel pada prestasi belajar telah memenuhi asumsi saling berkorelasi yaitu dengan melihat nilai Sig. sebesar 1,709e-11 yang lebih kecil dari $\alpha=5 \%$, maka tolak $\mathrm{H}_{0}$, yang menunjukkan bahwa matriks korelasi bukan merupakan matriks identitas sehingga dapat dilakukan analisis komponen utama.

\section{Kaiser-Meyer-Olkin (KMO)}

Uji Kaiser-Meyer-Olkin (KMO) merupakan indeks yang digunakan untuk meneliti ketepatan analisis faktor. Mengacu pada landasan teori bahwa sekelompok data dikatakan memenuhi asumsi kecukupan data apabila nilai KMO lebih besar daripada 0,5. Hipotesis yang digunakan dalam uji KMO adalah sebagai berikut (Usman dan Sobari, 2013):
$\mathrm{H}_{0}$ : jumlah data cukup untuk difaktorkan

$\mathrm{H}_{1}$ : jumlah data tidak cukup untuk difaktorkan

Dalam analisis faktor nilai Kaiser-Meyer-Olkin (KMO) sebesar 0,5 sampai 1,0, menunjukan bahwa proses analisis faktor dilakukan sudah tepat dan dapat dilanjutkan. Pada hasil pengujian KMO dengan software R, diketahui bahwa nilai KaiserMeyer-Olkin (KMO) yang diperoleh adalah sebesar $0,664>0,5$. Hal ini berarti jumlah data cukup untuk difaktorkan. Nilai Kaiser-Meyer-Olkin (KMO) tersebut didapatkan setelah dilakukan pengujian ulang karena pada uji persyaratan Measure of Sampling Adequacy (MSA) terdapat variabel yang korelasinya tidak signifikan sehingga harus dikeluarkan.

\section{Measure of Sampling Adequacy (MSA)}

Hasil pengujian Measure of Sampling Adequacy (MSA) yang disajikan merupakan hasil uji MSA tahap 2 (dua), karena pada hasil uji tahap pertama terdapat 2 (dua) variabel yang memiliki nilai MSA kurang dari 0,5 yaitu pada variabel karakter guru yang baik menumbuhkan semangat belajar siswa (X6) dan rasa ingin tau siswa terhadap pelajaran sangat tinggi (X25). Hal ini dapat disimpulkan bahwa 2 (dua) variabel tersebut tidak dapat diprediksi dan tidak bisa dianalisis lebih lanjut, dan harus dikeluarkan dari variabel lain. Berikut adalah hasil Uji MSA tahap 2 (dua)

Tabel 5. Uji Measure of Sampling Adequacy

\begin{tabular}{crl}
\multicolumn{2}{c}{ (MSA) Tahap 2 } & \\
\hline Variabel & NilaiMSA & Keputusan \\
\hline X2 & 0,797 & Dilanjutkan \\
X3 & 0,525 & Dilanjutkan \\
X5 & 0,748 & Dilanjutkan \\
X8 & 0,620 & Dilanjutkan \\
X9 & 0,691 & Dilanjutkan \\
X11 & 0,705 & Dilanjutkan \\
X13 & 0,593 & Dilanjutkan \\
X14 & 0,695 & Dilanjutkan \\
X15 & 0,510 & Dilanjutkan \\
X16 & 0,630 & Dilanjutkan \\
X17 & 0,668 & Dilanjutkan \\
X18 & 0,647 & Dilanjutkan \\
X19 & 0,621 & Dilanjutkan \\
X20 & 0,755 & Dilanjutkan \\
X22 & 0,783 & Dilanjutkan \\
X24 & 0,636 & Dilanjutkan \\
X27 & 0,733 & Dilanjutkan \\
X28 & 0,729 & Dilanjutkan \\
\hline
\end{tabular}

Berdasarkan hasil pengujian ulang pada Tabel 5 di atas menunjukan bahwa semua nilai MSA masingmasing variabel lebih besar dari 0,5 (Hendra, 2017): Hal ini dapat disimpulkan bahwa adanya korelasi 
yang signifikan antar variabel, sehingga dapat dilanjutkan ke tahap analisis faktor.

\section{Communalities}

Communalities pada dasarnya adalah jumlah varians (bisa dalam persentase) dari suatu variabel asal yang bisa dijelaskan oleh faktor yang ada (Santoso, 2014). Berikut ini hasil communalities :

Tabel 6. Nilai Communalities

\begin{tabular}{cr}
\hline Variabel & Extraction (h2) \\
\hline X2 & 0,54 \\
X3 & 0,65 \\
X5 & 0,76 \\
X8 & 0,55 \\
X9 & 0,57 \\
X11 & 0,73 \\
X13 & 0,68 \\
X14 & 0,75 \\
X15 & 0,85 \\
X16 & 0,58 \\
X17 & 0,67 \\
X18 & 0,51 \\
X19 & 0,64 \\
X20 & 0,66 \\
X22 & 0,58 \\
X24 & 0,77 \\
X27 & 0,42 \\
X28 & 0,49 \\
\hline
\end{tabular}

Berdasarkan Tabel 6 dapat dijelaskan bahwa variabel cara mengajar guru menumbuhkan semangat belajar (X5) dengan nilai Communal Extraction sebesar 0,76 hal ini berarti keterkaitan variabel tersebut (X5) terhadap faktor yang terbentuk adalah sebesar 76\%. Kemudian pada variabel siswa mencari solusi saat mengalami kesulitan (X15) memiliki nilai Communal Extraction sebesar 0,85 ini juga berarti sebesar $85 \%$ variabel tersebut (X15) bisa dijelaskan oleh faktor yang terbentuk. Demikian seterusnya untuk variabel lainnya, dengan ketentuan semakin besar communalities sebuah variabel, maka semakin erat hubungan dengan faktor yang terbentuk

\section{Total Variance Explained}

Total Variance Explained berfungsi untuk menerangkan nilai persen dari varians yang mampu diterangkan oleh banyaknya faktor yang terbentuk. Nilai ini didasarkan dari nilai eigenvalue menggambarkan kepentingan relative masingmasing faktor dalam menghitung varians dari 18 variabel yang dianalisis. Berdasarkan nilai eigenvalue yang diambil, untuk menentukan berapa banyak faktor yang terbentuk adalah nilai eigenvalue yang lebih besar dari satu (Subash Sharma, 1996).
Tabel 7. Total Variance Explained

\begin{tabular}{lrrr}
\hline & $\begin{array}{l}\text { Eigen } \\
\text { value }\end{array}$ & \multicolumn{1}{l}{$\begin{array}{l}\text { Varian } \\
\text { Perces }\end{array}$} & $\begin{array}{l}\text { Cumulativ } \\
\text { e Variance } \\
\text { persen }\end{array}$ \\
\hline Dim.1 & 4,869 & 28,642 & 28,642 \\
Dim.2 & 2,054 & 12,085 & 40,728 \\
Dim.3 & 1,724 & 10,145 & 50,874 \\
Dim.4 & 1,263 & 7,432 & 58,307 \\
Dim.5 & 1,029 & 6,055 & 64,362 \\
Dim.6 & 0,886 & 5,214 & 69,576 \\
Dim.7 & 0,868 & 5,107 & 74,684 \\
Dim.8 & 0,719 & 4,229 & 78,914 \\
Dim.9 & 0,690 & 4,061 & 82,975 \\
Dim.10 & 0,648 & 3,814 & 86,789 \\
Dim.11 & 0,538 & 3,165 & 89,955 \\
Dim.12 & 0,451 & 2,655 & 92,611 \\
Dim.13 & 0,399 & 2,351 & 94,962 \\
Dim.14 & 0,348 & 2,048 & 97,010 \\
Dim.15 & 0,197 & 1,159 & 98,170 \\
Dim.16 & 0,161 & 0,950 & 99,120 \\
Dim.17 & 0,149 & 0,879 & 100,000 \\
Dim.26 & 0,298 & 1,067 & 98,354 \\
Dim.27 & 0,255 & 0,914 & 99,268 \\
Dim.28 & 0,204 & 0,731 & 100,000 \\
\hline & & &
\end{tabular}

Hasil uji Total Variance Explained pada Tabel 7 dapat diketahui bahwa nilai eigenvalue yang lebih dari satu terbentuk sebanyak 5 faktor yang dapat mewakili variabel.

Tabel 8. Hasil Reduksi Variabel

\begin{tabular}{|l|c|c|c|c|c|}
\hline & PC5 & PC3 & PC2 & PC1 & PC4 \\
\hline Proportion Var & 0,15 & 0,14 & 0,14 & 0,12 & 0,08 \\
\hline Cumulative Var & 0,15 & 0,29 & 0,43 & 0,55 & 0,63 \\
\hline
\end{tabular}

Berdasarkan Tabel 8 di atas, proportion variance untuk PC5 (faktor 5) adalah sebesar 0,15, artinya faktor 5 mampu menjelaskan variansi dari 18 variabel sebesar 15\%. Kemudian untuk PC3 (faktor 3) dan PC2 (faktor 2) mampu menjelaskan variansi dari keseluruhan variabel yang di amati sebesar $14 \%$, sedangkan untuk faktor PC1 (faktor 1) mampu menjelaskan variansi dari 18 variabel sebesar $12 \%$. Dan pada PC4 (faktor 4) hanya mampu menjelaskan variansi dari 18 variabel sebanyak $8 \%$

Cumulative variance menunjukan gabungan dari beberapa atau keseluruhan nilai proportion variance faktor dalam menjelaskan 18 variabel tersebut. Misalkan nilai 0,29 menunjukan gabungan dari proportion variance PC5 (faktor 5) dan PC3 (faktor 3) yaitu $0,15+0,14=0,29$. Artinya adalah variansi dari 18 variabel mampu dijelaskan oleh PC5 dan PC3 sebesar 29\%. Sedangkan untuk kelima 
faktor yang terbentuk mampu menjelaskan variansi dari 18 variabel sebesar $63 \%$.

\section{Rotasi Faktor}

Rotated Component Matrix memuat nilai loading factor dari setiap variabel untuk masingmasing faktor baru yang terbentuk. Loading factor merupakan besarnya korelasi antara faktor skor dan variabel tersebut. Rotasi dilakukan dengan metode varimax terhadap faktor-faktor yang akan terbentuk.

Berikut hasil pengujian untuk melihat Rotated Component Matrix menggunakan software R :

Tabel 9. Rotated Component Matrix

\begin{tabular}{lrrrrr}
\hline \multirow{2}{*}{ Varriabel } & \multicolumn{5}{c}{ Component } \\
\cline { 2 - 6 } & PC5 & PC3 & PC2 & PC1 & PC4 \\
\hline X2 & $-0,06$ & $\mathbf{0 , 6 5}$ & 0,20 & 0,06 & 0,22 \\
X3 & 0,00 & $\mathbf{0 , 7 4}$ & 0,25 & 0,01 & $-0,19$ \\
X5 & 0,15 & 0,41 & 0,22 & $\mathbf{0 , 7 2}$ & $-0,04$ \\
X8 & 0,16 & 0,21 & $\mathbf{0 , 6 7}$ & 0,18 & $-0,02$ \\
X9 & $-0,09$ & 0,02 & $\mathbf{0 , 7 2}$ & 0,17 & 0,12 \\
X11 & $\mathbf{0 , 7 4}$ & 0,05 & 0,26 & 0,29 & $-0,17$ \\
X13 & $\mathbf{0 , 6 7}$ & $-0,01$ & $-0,13$ & 0,45 & $-0,11$ \\
X14 & $\mathbf{0 , 6 3}$ & $-0,12$ & 0,30 & $-0,06$ & 0,49 \\
X15 & 0,00 & 0,19 & 0,21 & 0,14 & $\mathbf{0 , 8 7}$ \\
X16 & 0,10 & 0,15 & 0,26 & 0,03 & $\mathbf{0 , 6 3}$ \\
X17 & $\mathbf{0 , 6 1}$ & 0,31 & $-0,22$ & 0,30 & 0,27 \\
X18 & $\mathbf{0 , 5 3}$ & 0,38 & $-0,17$ & 0,15 & 0,19 \\
X19 & 0,30 & $\mathbf{0 , 6 9}$ & $-0,14$ & 0,19 & 0,13 \\
X20 & $\mathbf{0 , 6 7}$ & 0,09 & $-0,41$ & $-0,16$ & $-0,02$ \\
X22 & 0,11 & $-0,07$ & $\mathbf{0 , 7 1}$ & 0,14 & 0,20 \\
X24 & 0,10 & $-0,12$ & 0,51 & $\mathbf{0 , 6 9}$ & $-0,03$ \\
X27 & 0,20 & 0,33 & 0,06 & $\mathbf{0 , 5 0}$ & 0,10 \\
X28 & 0,09 & $\mathbf{0 , 6 5}$ & $-0,15$ & 0,19 & 0,07 \\
\hline
\end{tabular}

Berdasarkan hasil loading factor pada Tabel 9 diatas, penentuan faktor dari variabel adalah dengan melihat nilai matrix korelasi terbesar. Misalnya nilai terbesar untuk matris korelasi variabel X5 terdapat pada komponen PC1 (Faktor 1) yaitu 0,72, maka variabel X5 masuk di faktor 1. Begitu juga untuk variabel X13, matrikx korelasi terbesar berada pada komponen PC3 (Faktor 3) dengan nilai korelasi sebesar 0,67 maka variabel X13 masuk di faktor 3 .

Sehingga dari keseluruhan hasil output dapat disimpulkan, faktor-faktor yang dapat meningkatkan pretasi belajar siswa kelas X IPS di SMA Negeri 1 Adonara Timur dapat dikelompokan sebagai berikut:
Tabel 10. Pengelompokan Variabel

\begin{tabular}{|c|c|}
\hline Faktor & Variabel \\
\hline \multirow{3}{*}{$\begin{array}{l}\text { Faktor } 1 \\
\text { (Lingkungan } \\
\text { Sekolah }\end{array}$} & $\begin{array}{l}\text { Cara mengajar guru menumbuhkan } \\
\text { semangat belajar (X5) }\end{array}$ \\
\hline & $\begin{array}{l}\text { Memanfaatkan waktu untuk belajar } \\
\text { ketika guru berhalangan masuk } \\
\text { (X24) }\end{array}$ \\
\hline & $\begin{array}{l}\text { Memiliki hubungan yang harmonis } \\
\text { dengan teman (X27) }\end{array}$ \\
\hline \multirow{3}{*}{$\begin{array}{l}\text { Faktor } 2 \\
\text { (Peranan } \\
\text { Orang tua) }\end{array}$} & $\begin{array}{l}\text { Orang tua memberi semangat saat } \\
\text { hasil belajar kurang baik (X8) }\end{array}$ \\
\hline & $\begin{array}{l}\text { Orang tua memberikan pujian jika } \\
\text { hasil belajar memuaskan (X9) }\end{array}$ \\
\hline & $\begin{array}{l}\text { Mengerjakan tugas tepat waktu di } \\
\text { rumah (X22) }\end{array}$ \\
\hline \multirow{4}{*}{$\begin{array}{l}\text { Faktor } 3 \\
\text { (Peranan } \\
\text { Guru) }\end{array}$} & $\begin{array}{l}\text { Guru membantu siswa jika } \\
\text { mengalami kesulitan belajar (X2) }\end{array}$ \\
\hline & $\begin{array}{l}\text { Guru mampu menciptakan rasa } \\
\text { nyaman dalam belajar di kelas (X3) }\end{array}$ \\
\hline & $\begin{array}{l}\text { Bertanya kepada guru jika belum } \\
\text { memahami penjelasannya (X19) }\end{array}$ \\
\hline & $\begin{array}{l}\text { Memiliki Hubungan yang harmonis } \\
\text { dengan guru (X28) }\end{array}$ \\
\hline \multirow{2}{*}{$\begin{array}{l}\text { Faktor } 4 \\
\text { (Disiplin } \\
\text { Belajar) }\end{array}$} & $\begin{array}{l}\text { Mencari solusi ketika mengalami } \\
\text { kesulitan belajar (X15) }\end{array}$ \\
\hline & $\begin{array}{l}\text { Mempelajari kembali materi yang } \\
\text { diajarkan guru di rumah (X16) }\end{array}$ \\
\hline \multirow{6}{*}{$\begin{array}{l}\text { Faktor } 5 \\
\text { (Motivasi } \\
\text { Belajar) }\end{array}$} & $\begin{array}{l}\text { Ambisi untuk berhasil dalam } \\
\text { belajar tinggi (X11) }\end{array}$ \\
\hline & $\begin{array}{l}\text { Membuat jadwal belajar sendiri } \\
\text { (X13) }\end{array}$ \\
\hline & $\begin{array}{l}\text { Tetap giat belajar meskipun nilai } \\
\text { ulangan baik (X14) }\end{array}$ \\
\hline & $\begin{array}{l}\text { Mengerjakan sendiri tugas yang } \\
\text { diberikan guru (X17) }\end{array}$ \\
\hline & $\begin{array}{l}\text { Memperhatikan penjelasan guru } \\
\text { (X18) }\end{array}$ \\
\hline & $\begin{array}{l}\text { Mencatat penjelasan penting dari } \\
\text { guru (X20) }\end{array}$ \\
\hline
\end{tabular}

Berdasarkan data hasil penelitian di sekolah, setelah data dikumpulkan dan dipelajari kemudian dianalisis menggunakan Software $R$, diperoleh suatu gambaran hasil penelitian tentang beberapa faktor yang dapat meningkatkan prestasi belajar siswa kelas X IPS SMA Negeri 1 Adonara Timur, diantaranya lingkungan sekolah, peranan orang tua, peranan guru, modernitas individu, dan motivasi belajar. Kelima faktor ini diperoleh dari 18 faktor yang dirotasikan dengan nilai loading factor terbesar. Dari 18 variabel ini membentuk 5 (lima) faktor yang dikatakan dapat meningkatkan prestasi belajar siswa kelas X IPS di SMA Neregi 1 Adonara Timur.

Pada Tabel 10 menunjukan bahwa terdapat 5 (lima) faktor yang terbentuk yang dapat meningkatkan prestasi belajar siswa kelas X IPS. Faktor pertama (PC1) yaitu lingkungan sekolah 
yang meliputi 3 variabel, diantaranya: cara mengajar guru menumbuhkan semangat belajar, memanfaatkan waktu untuk belajar ketika guru berhalangan masuk, dan memiliki hubungan yang harmonis dengan teman. Faktor kedua (PC2) yaitu peranan orang tua yang terdiri dari 3 (tiga) variabel diantaranya: orang tua memberi semangat saat hasil belajar kurang baik, orang tua memberikan pujian jika hasil belajar memuaskan, dan mengerjakan tugas tepat waktu di rumah. Faktor ketiga (PC3) yaitu peranan guru yang terdiri dari 4 (empat) variabel diantaranya: guru membantu siswa jika mengalami kesulitan belajar, guru mampu menciptakan rasa nyaman dalam belajar di kelas, bertanya kepada guru jika belum memahami penjelasannya, dan memiliki Hubungan yang harmonis dengan guru. Faktor keempat (PC4) yaitu disiplin belajar yang terdiri dari 2 (dua) variabel diantaranya: mencari solusi ketika mengalami kesulitan belajar dan mempelajari kembali materi yang diajarkan guru di rumah. Faktor kelima (PC5) yaitu motivasi belajar yang terdiri dari 6 variabel diantaranya: ambisi untuk berhasil dalam belajar tinggi, membuat jadwal belajar sendiri, tetap giat belajar meskipun nilai ulangan baik, mengerjakan sendiri tugas yang diberikan guru, memperhatikan penjelasan guru, dan mencatat penjelasan penting dari guru.

\section{KESIMPULAN DAN SARAN}

Berdasarkan hasil analisis pembahasan yang telah dikemukan pada bab sebelumnya, maka dapat disimpulkan bahwa: Faktor-faktor yang diduga dapat meningkatkan prestasi belajar siswa kelas $\mathrm{X}$ IPS SMA Negeri 1 Adonara Timur, terdapat 5 (lima) faktor yang terbentuk yaitu Faktor Lingkungan sekolah, Faktor Peranan Orang tua, Faktor Peranan guru, Faktor Disiplin belajar, dan Faktor Motivasi belajar.

1. Faktor Lingkungan Sekolah terdiri dari variabel cara mengajar guru menumbuhkan semangat belajar, memanfaatkan waktu untuk belajar ketika guru berhalangan masuk, dan memiliki hubungan yang harmonis dengan teman.

2. Faktor Peranan Orang Tua terdiri dari variabel orang tua memberi semangat saat hasil belajar kurang baik, orang tua memberikan pujian jika hasil belajar memuaskan, dan mengerjakan tugas tepat waktu di rumah.

3. Faktor Peranan Guru terdiri dari variabel guru membantu siswa jika mengalami kesulitan belajar, guru mampu menciptakan rasa nyaman dalam belajar di kelas, bertanya kepada guru jika belum memahami penjelasannya, dan memiliki Hubungan yang harmonis dengan guru.

4. Faktor Disiplin Belajar terdiri dari variabel mencari solusi ketika mengalami kesulitan belajar dan mempelajari kembali materi yang diajarkan guru di rumah.

5. Faktor Motivasi Belajar terdiri dari variabel ambisi untuk berhasil dalam belajar tinggi, membuat jadwal belajar sendiri, tetap giat belajar meskipun nilai ulangan baik, mengerjakan sendiri tugas yang diberikan guru, memperhatikan penjelasan guru, dan mencatat penjelasan penting dari guru.

Berdasarkan hasil yang diperoleh dari penelitian ini, maka diajukan saran sebagai berikut:

1. Berdasarkan hasil penelitian yang diperoleh berupa faktor-faktor yang telah terbentuk, pihak sekolah SMA Negeri 1 Adonara Timur dapat menggunakannya sebagai bahan pertimbangan untuk meningkatkan prestasi belajar siswa.

2. Bagi peneliti selanjutnya, diharapkan dapat meneliti dengan populasi yang lebih luas lagi dan mencari faktor-faktor

\section{DAFTAR PUSTAKA}

Nasution. 2009. Berbagai Pendekatan Dalam Proses Belajar dan Mengajar. Jakarta: PT Bumi Aksara.

Farida, N. 2013. Faktor-Faktor yang Mempengaruhi Prestasi Belajar Siswa Kelas X IPS SMA Negeri Ponorogo. Jurnal Program FKIP, Universitas Sebelaas Maret.

Sharma, S. 1996. Applied Multivariate Technicgues, John Wiley \& Sons, Inc, New York.

Santoso, S. 2012. Aplikasi SPSS Pada Statistik Multivariat. Jakarta: PT. Elex Media Komputindo.

Hendra, S. 2017. Metode Analisis Faktor. https://statmat.id/panduan-menguasai-metodeanalisis-faktor/. Tanggal unduh 21 Januari 2018.

Usman, H. dan Sobari, N. 2013. Aplikasi Teknik Multivariate untuk Riset Pemasaran. Jakarta: Rajawali Pres.

Jhonson \& Wichern. 2002. Multivariate Statistical Analysis. New Jersey: Pretice Hall

Baroroh, A. 2013. Analisis Multivariat dan Time Series dengan SPSS 21. Jakarta: PT. Elex Media Komputindo.

Supranto, J. 2004. Analisis Multivariate: Arti dan interpretasi, Jakarta, PT. Rineka Cipta 